\title{
Pendekatan Pembelajaran Open Ended terhadap Peningkatan Kemampuan Pemahaman Matematis Siswa SMP
}

\author{
Giyarti \\ SMP Negeri 2 Mande \\ *giyarti0465@gmail.com
}

\begin{tabular}{|l|l|l|l|}
\hline Received : 21-10-2021 & Revised: 01-12-2021 & Accepted: 03-12-2021 & Published: 21-12-2021 \\
\hline
\end{tabular}

\begin{abstract}
ABSTRAK
Kemampuan pemahaman matematis artinya materi yang diajarkan kepada siswa bukan hanya sebagai hapalan, namun lebih dari itu dengan pemahaman siswa dapat lebih mengerti akan konsep materi pelajaran itu sendiri. Dalam kenyataannya kemampuan pemahaman matematis ini kurang mampu dimaksimalkan dalam pencapaiannya di sekolah, termasuk di SMP Negeri 2 Mande. Salah satu pendekatan yang mampu mengoptimalkan kemampuan pemahaman matematis siswa adalah pendekatan open ended. Pendekatan open ended menyajikan problem yang diformulasikan memiliki multijawaban yang benar disebut juga problem tak lengkap atau soal terbuka. Dari hasil analisis data menunjukkan bahwa: terdapat pencapaian dan peningkatan kemampuan pemahaman matematis siswa yang lebih baik dari siswa yang belajar dengan menggunakan pendekatan open ended daripada siswa yang belajar dengan menggunakan pendekatan konvensional, hampir seluruhnya siswa memiliki sikap positif terhadap pembelajaran matematika dengan menggunakan pendekatan open ended, terdapat korelasi positif antara sikap sikap siswa terhadap pembelajaran matematika menggunakan pendekatan open ended dengan peningkatan kemampuan pemahaman matematis siswa. Berdasarkan pembahasan diperoleh kesimpulan bahwa pendekatan pembelajaran open ended berpengaruh terhadap peningkatan kemampuan pemahaman matematis.
\end{abstract}

Kata Kunci: kemampuan pemahaman matematis, pendekatan open ended

\begin{abstract}
Mathematical understanding ability means that the material taught to students is not only memorized, but more than that, with understanding students can better understand the concept of the subject matter itself. In reality, this mathematical understanding ability is less able to be maximized in its achievement in schools, including at SMP Negeri 2 Mande. One approach that is able to optimize students' mathematical understanding abilities is an open-ended approach. The open-ended approach presents problems that are formulated to have multiple correct answers, which are also called incomplete problems or open questions. From the results of data analysis shows that: there is an achievement and improvement in students' mathematical understanding abilities that are better than students who learn using an open ended approach than students who learn using a conventional approach, almost all students have a positive attitude towards learning mathematics using an open ended approach., there is a positive correlation between students' attitudes towards learning mathematics using an open-ended approach and increasing students' mathematical understanding abilities. Based on the discussion, it can be concluded that the openended learning approach has an effect on increasing mathematical understanding abilities.
\end{abstract}

Keywords: mathematical understanding ability, open ended approach 


\section{PENDAHULUAN}

Pandangan modern tentang pendidikan menuntut untuk lebih menekankan pada peserta didik sebagai manusia yang memiliki potensi untuk belajar dan berkembang (Fatwa, Septian, \& Inayah, 2019). Siswa harus aktif dalam penemuan dan pengembangan pengetahuan. Melalui pandangan baru tersebut diharapkan di kelas siswa aktif dalam dalam kegiatan belajar, bisa mengemukakan gagasan dari suatu permasalahan yang dihadapi secara beragam (Maskur et al., 2020). Matematika sebagai salah satu disiplin ilmu yang berperan penting dalam dunia pendidikan, menjadi penyokong perkembangan berbagai ilmu pengetahuan dan teknologi. Pembelajaran matematika diharapkan dapat menumbuhkembangkan kemampuan bernalar yaitu berpikir sistematis, logis dan kritis dalam mengkomunikasikan gagasan atau ide (Sudiarta, Sukajaya, \& Suharta, 2018; Suwarman, 2018).

Pemahaman diartikan sebagai penyerapan arti suatu materi yang dipelajari. Lebih lanjut Michener menyatakan bahwa pemahaman merupakan salah satu aspek dalam Taksonomi Bloom (Monariska, 2017). Pemahaman diartikan sebagai penyerapan arti suatu materi bahan yang dipelajari. Untuk memahami suatu objek secara mendalam seseorang harus mengetahui objek itu sendiri, relasinya dengan objek lain yang sejenis, relasinya dengan objek lain yang tidak sejenis, relasi dual dengan objek lainnya yang sejenis dan relasi dengan objek dalam teori lainnya (Dini, Nuraeni, \& Anita, 2018; Rahmi, Usman, \& Subianto, 2020).

Matematika sebagai salah satu mata pelajaran yang diajarkan mulai dari jenjang pendidikan dasar, matematika juga merupakan mata pelajaran yang berkaitan dengan konsep-konsep yang abstrak (Komala Sari, Syazali, \& Farida, 2016). Dengan adanya hal tersebut matematika harus dapat disajikan secara lebih menarik dan sesuai dengan kondisi dan keadaan siswa (Rizkiani \& Septian, 2019; Septian, Darhim, \& Prabawanto, 2020). Hal ini tentu saja dimaksudkan agar dalam proses pembelajaran siswa lebih aktif dan termotivasi untuk belajar. Oleh karena itu, perlu adanya pendekatan khusus yang diterapkan oleh guru.

Gurulah yang menjadi ujung tombak berhasil atau tidaknya pencapaian tujuan belajar mengajar di sekolah (Sari \& Hayati, 2019). Selama ini rendahnya kualitas belajar siswa yang berpengaruh terhadap hasil matematika siswa lebih banyak disebabkan karena pendekatan, metode, ataupun strategi tertentu yang digunakan oleh guru dalam proses pembelajaran masih bersifat tradisional, dan kurang memberikan kesempatan kepada siswa 
untuk mengembangkan pola pikirnya sesuai dengan kemampuan masing-masing (Krawec, 2014). Akibatnya kemampuan berpikir matematika dan pemahaman matematis siswa tidak dapat berkembang secara optimal. Oleh karena itu, guru perlu memilih cara mengajar atau pendekatan yang dapat membantu mengembangkan pola pikir matematika siswa.

Strategi ini disesuaikan dengan kebutuhan, situasi dan kondisi sehingga pelaksanaan pembelajaran berjalan lancar yang pada akhirnya akan mencapai hasil yang optimal (Tsany, Septian, \& Komala, 2020). Pembelajaran tradisional dirasakan sudah tidak relevan dengan situasi dan kondisi saat ini sebab pembelajaran seperti ini lebih berpusat pada guru, sedangkan siswa lebih bersifat pasif yakni duduk, diam, mendengar, dan mencatat apa yang disampaikan guru (Rohaendi \& Laelasari, 2020).

Salah satu pendekatan pembelajaran yang dianggap baik untuk diterapkan dalam proses pembelajaran dan bisa meningkatkan kemampuan pemahaman matematis siswa adalah pendekatan terbuka (open ended) (Dewi, 2018; Ekici, 2017; Zengin, 2019). Pembelajaran ini melatih dan menumbuhkan orisinilitas ide, kreativitas, kognitif tinggi, kritis, komunikasi-interaksi, sharing, keterbukaan, dan sosialisasi. Siswa dituntut untuk berimprovisasi mengembangkan metode, cara, atau pendekatan yang bervariasi dalam memperoleh jawaban, dan atau jawaban siswa beragam (Dewi, 2018). Dengan demikian model pembelajaran ini lebih mementingkan proses daripada produk yang akan membentuk pola pikir, keterpasungan, keterbukaan, dan ragam berpikir.

SMP Negeri 2 Mande merupakan salah satu sekolah menengah negeri yang ada di lingkungan Kabupaten Cianjur. Siswa-siswi dari sekolah ini memiliki potensi yang cukup baik dalam mata pelajaran matematika. Segala potensi yang ada dalam diri siswa tidak akan mampu mendapat hasil belajar yang optimal, apabila guru tidak mampu menciptakan kualitas belajar matematika yang baik. Hal ini akan berimbas pada rendahnya pencapaian tujuan pembelajaran yang telah dirancang sebelumnya.

Berdasarkan hal tersebut, rumusan masalah dalam penelitiani ini bertujuan untuk menganalisa perbandingan kemampuan pemahaman matematis siswa yang belajar dengan pendekatan open ended dan siswa yang belajar dengan pendekatan konvensional, sikap siswa terhadap kegiatan pembelajaran menggunakan pendekatan open ended, serta korelasi sikap siswa terhadap pendekatan open ended dengan peningkatan kemampuan pemahaman matematis siswa. 


\section{METODOLOGI PENELITIAN}

Metode yang digunakan dalam penelitian ini adalah metode kuasi eksperimen. Penelitian ini disebut kuasi eksperimen, karena penelitian ini bukan merupakan eksperimen murni atau disebut eksperimen semu. Kuasi eksperimen digunakan berkenaan dengan pengontrolan variabel yang kemungkinannya sukar jika digunakan metode eksperimen murni. Dalam penelitian ini, peneliti mengajukan beberapa hipotesis yang telah dibahas pada bab sebelumnya yang menyatakan sifat dari korelasi variabel tersebut. Dengan demikian, perlakuan variabel bebas (manipulasi) yang dilakukan pada penelitian ini adalah pembelajaran dengan menggunakan pendekatan pembelajaran open ended. Sedangkan variabel terikat sebagai aspek yang diamati/diukur adalah kemampuan pemahaman matematis siswa.

Penelitian ini menggunakan dua kelompok yaitu kelompok eksperimen dan kelompok kontrol. Desain yang digunakan dalam penelitian ini yaitu " Control group pretest posttest”. Kelompok pertama sebagai eksperimen dan kelompok kedua sebagai kelompok kontrol. Kelompok eksperimen menggunakan pendekatan pembelajaran open ended, sedangkan kelas kontrol menggunakan pembelajaran konvensional. Penelitian ini dilaksanakan di SMP Negeri 2 Mande dengan populasi seluruh siswa kelas VII SMP Negeri 2 Mande Tahun Pelajaran 2020/2021, dan diperoleh dua kelas yaitu kelas VII-E dan VII-G.

Adapun instrumen penelitian adalah instrumen tes berupa 5 butir soal uraian dan instrumen non tes berupa angket skala sikap yang terdiri dari 16 pernyataan positif dan 14 pernyataan negatif. Sebelum digunakan, instrumen tersebut diujicobakan terlebih dahulu. Soal tes diujicoba untuk mengetahui validitas, reliabilitas, indeks kesukaran, dan daya pembeda. Sedangkan angket skala sikap diujicoba untuk mengetahui tingkat keterbacaan dari setiap pernyataan.

\section{HASIL PENELITIAN DAN PEMBAHASAN}

\section{Pretest Kemampuan Pemahaman Matematis Siswa}

Tabel 1. Deskripsi Statistik Skor Pretest

\begin{tabular}{lcccccc}
\hline \multicolumn{1}{c}{ Kelas } & $\begin{array}{c}\text { Skor } \\
\text { Ideal }\end{array}$ & \multicolumn{5}{c}{ Kemampuan Pemahaman Matematis } \\
\cline { 3 - 7 } & & Minimum & Maksimum & Mean & $\begin{array}{c}\text { Standar } \\
\text { Deviasi }\end{array}$ & Persentase \\
\hline Eksperimen & 100 & 5 & 53 & 24,18 & 12,78 & $24,18 \%$ \\
\hline Kontrol & 100 & 11 & 45 & 26,14 & 8,06 & $26,14 \%$ \\
\hline
\end{tabular}

Berdasarkan uji statistik dengan Independent Sample T' Test, diperoleh hasil sebagai berikut. 
Tabel 2. Uji Kesamaan Dua rata-rata Sampel Independen Data Skor Pretest

$$
\begin{array}{cc}
\text { Asymp. Sig. (2-tailed) } & \text { Keterangan } \\
0,433 & \mathrm{H}_{0} \text { diterima }
\end{array}
$$

$\mathrm{H}_{0}$ :Rata-rata kemampuan awal pemahaman matematis antara kelas eksperimen dan kelas kontrol setara.

Berdasarkan Tabel 1, skor maksimum ideal pretest adalah 100. Skor maksimum yang diperoleh siswa pada kelas eksperimen dan kelas kontrol berturut-turut adalah 53 dan 45. Sedangkan skor minimum kelas eksperimen dan kelas kontrol secara berturut-turut adalah 5 dan 11. Dari hasil perhitungan data skor kemampuan pemahaman matematis awal kelas eksperimen diperoleh rata-rata 24,18 dengan simpangan baku 12,78. Sedangkan untuk data skor kemampuan pemahaman matematis awal kelas kontrol diperoleh rata-rata 26,14 dengan simpangan baku 8,06.

Berdasarkan hasil uji kesamaan dua rata-rata independen pada Tabel 2 dengan Independent Sampel $T$ Test, diperoleh kesimpulan bahwa skor pretest pada kelas eksperimen dan kelas kontrol relatif sama. Dengan demikian siswa pada kelas eksperimen maupun kelas kontrol memiliki kemampuan pemahaman matematis awal yang sama saat penelitian dimulai.

\section{Pencapaian Kemampuan Pemahaman Matematis Siswa}

Tabel 3. Deskripsi Statistik Skor Posttest

\begin{tabular}{lcccccc}
\hline Kelas & Skor & \multicolumn{5}{c}{ Kemampuan Pemahaman Matematis } \\
\cline { 6 - 8 } & Ideal & Minimum & Maksimum & Mean & $\begin{array}{c}\text { Standar } \\
\text { Deviasi }\end{array}$ & Persentase \\
& 100 & 47 & 100 & 77,82 & 15,91 & $77,82 \%$ \\
\hline Eksperimen & 100 & 41 & 100 & 63,49 & 17,19 & $63,49 \%$ \\
\hline Kontrol & 100 & & & & &
\end{tabular}

Berdasarkan uji statistik dengan menggunakan Independent Sample T' Test, diperoleh hasil sebagai berikut.

Tabel 4. Uji Perbedaan Dua Rata-Rata Sampel Independen Data Skor Posttest

\begin{tabular}{cl}
\hline Asymp. Sig. (2-tailed) & Keterangan \\
\hline 0,000 & $\mathrm{H}_{1}$ diterima \\
\hline
\end{tabular}

$\mathrm{H}_{1}$ : Pencapaian kemampuan pemahaman matematis siswa yang mendapat pembelajaran matematika dengan pendekatan open ended lebih baik daripada siswa yang mendapat pembelajaran konvensional.

Dari deskripsi hasil pengolahan data pada Tabel 3 nilai posttest pada kelas eksperimen diperoleh rata-rata sebesar 77,82 dengan simpangan baku 15,91. Sedangkan 
dari deskripsi hasil pengolahan pada nilai posttest pada kelas kontrol diperoleh rata-rata sebesar 63,49 dengan simpangan baku 17,19. Tabel 4 menunjukkan bahwa nilai signifikansi kurang dari 0,05, hal tersebut menandakan bahwa pencapaian kemampuan pemahaman matematis siswa yang belajar dengan pendekatan open ended lebih baik dibandingkan dengan siswa yang belajar dengan pendekatan konvensional.

\section{Peningkatan Kemampuan Pemahaman Matematis Siswa}

Tabel 5. Deskripsi Statistik Data Skor Indeks Gain

\begin{tabular}{lcccrrr}
\hline Kelas & Skor & \multicolumn{4}{c}{ Kemampuan Pemahaman Matematis } \\
\cline { 3 - 7 } & Ideal & Minimum & Maksimum & Mean & $\begin{array}{l}\text { Standar } \\
\text { Deviasi }\end{array}$ & Persentase \\
\hline Eksperimen & 1,00 & 0,33 & 1,00 & 0,7175 & 0,225 & $71,75 \%$ \\
\hline Kontrol & 1,00 & 0,20 & 1,00 & 0,5141 & 0,211 & $51,41 \%$ \\
\hline
\end{tabular}

Berdasarkan uji statistik nonparametrik dengan menggunakan Uji Mann-Whitney, diperoleh hasil sebagai berikut.

Tabel 6. Hasil Uji Perbedaan Dua Rata-Rata Sampel Independen Indeks Gain

\begin{tabular}{cc}
\hline Asymp. Sig. (2-tailed) & Keterangan \\
\hline 0,000 & $\mathrm{H}_{1}$ diterima \\
\hline
\end{tabular}

$\mathrm{H}_{1}$ : Peningkatan kemampuan pemahaman matematis siswa yang mendapat pembelajaran matematika dengan pendekatan open ended lebih baik daripada siswa yang mendapat pembelajaran konvensional.

Dari deskripsi hasil perhitungan data pada Tabel 5 diperoleh rata-rata gain siswa pada kelas eksperimen dan kelas kontrol menunjukkan hasil yang bervariasi. Pada kelas eksperimen yang belajar menggunakan pendekatan open ended diperoleh rata-rata 0,7175 dengan simpangan baku 0,225. Sedangkan pada kelas kontrol yang belajar menggunakan pendekatan konvensional diperoleh rata-rata 0,5141 dengan simpangan baku 0,211. Selain itu, setelah dilakukan uji perbedaan dua rata-rata sampel independen pada Tabel 6 diperoleh hasil bahwa kedua kelas memiliki perbedaan yang signifikan dimana rata-rata siswa kelas eksperimen lebih baik dari kelas kontrol. Hasil tersebut menandakan bahwa peningkatan kemampuan pemahaman matematis siswa yang belajar dengan pendekatan open ended lebih baik dibandingkan dengan siswa yang belajar dengan pendekatan konvensional.

Perbedaan pencapaian kemampuan pemahaman matematis siswa kelas eksperimen dan siswa kelas kontrol dapat disebabkan oleh perbedaan aktivitas belajar siswa dalam memahami prinsip-prinsip matematika (Sari \& Hayati, 2019). Pada kelas eksperimen, 
siswa terbiasa memahami prinsip matematika secara menyeluruh hal ini dilakukan dengan kebiasaan menyelesaikan soal-soal yang bersifat terbuka dalam memahami suatu persoalan. Hal ini sejalan dengan hasil penelitian Widiyawati, Septian, dan Inayah (2020), yang menyatakan bahwa pada kelompok eksperimen memiliki kebiasaan berbeda yaitu lebih memahami soal dan dapat mengidentifkasinya.

Selain itu, siswa dihadapkan pada soal-soal yang bersifat tak rutin, soal-soal yang mengoptimalkan potensi pemikiran, karena mereka bisa mengajukan jawaban sendiri secara beragam tanpa menyalahi prinsip-prinsip matematika pada materi yang diajarkan. Hal ini sejalan juga dengan penelitian dari Widodo dan Kartikasari (2017) yang menyatakan bahwa ketika soal-soal bersifat tak rutin diberikan, maka siswa menjadi lebih terbuka, mengoptimalkan cara berpikirnya, dan menjawab sesuai prinsip. Hal tersebut berbeda dengan apa yang terjadi pada kelas kontrol yang belajar dengan pendekatan konvensional. Siswa hanya dilatih menyelesaikan soal-soal rutin, soal-soal yang bersifat melatih langkah per langkah menjawab soal rutin tanpa memberikan kesempatan kepada siswa untuk berpikir secara terbuka. Hal ini tentunya membatasi pemahaman siswa mengenai prinsip-prinsip materi yang diajarkan.

\section{Sikap Siswa Terhadap Pembelajaran Matematika dengan Menggunakan Pendekatan Open Ended (OE)}

Adapun secara keseluruhan sikap siswa terhadap pembelajaran matematika dengan menggunakan pendekatan open ended dapat dilihat pada tabel berikut.

Tabel 7. Rekapitulasi Sikap Siswa Secara Keseluruhan

\begin{tabular}{|c|c|c|c|}
\hline \multicolumn{3}{|c|}{ Persentase Sikap } & \multirow[t]{2}{*}{ Keterangan } \\
\hline Sikap Positif & Sikap Netral & Sikap Negatif & \\
\hline $82.81 \%$ & $6.75 \%$ & $10.44 \%$ & Hampir Seluruhnya Positif \\
\hline
\end{tabular}

Dari Tabel 7 dapat dilihat bahwa hampir seluruhnya sikap siswa terhadap pembelajaran matematika dengan menggunakan pendekatan open ended memiliki sikap yang positif. Sikap positif siswa tersebut dapat disebabkan oleh adanya perubahan suasana belajar (Budiman, 2019). Siswa antusias mencari jawaban berbeda dari permasalahan yang diberikan dalam bentuk soal-soal terbuka. Hal ini dirasakan berbeda ketika siswa belajar dengan pendekatan konvensional, dimana siswa hanya terampil menghapal rumus-rumus matematika dan dilatih menyelesaikan soal-soal matematika dengan langkah-langkah yang cenderung baku (Muhammad, 2017). 
Adapun sikap siswa secara keseluruhan dapat digambarkan kedalam diagram pada Gambar 1.

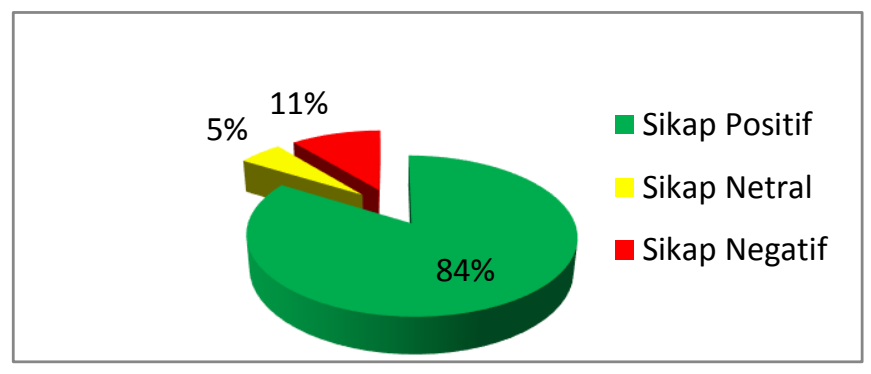

Gambar 1. Diagram Sikap Siswa Keseluruhan

Korelasi Sikap Siswa terhadap Pembelajaran Matematika dengan Menggunakan Pendekatan Open Ended dan Peningkatan Kemampuan Pemahaman Matematis Siswa

Korelasi antara sikap siswa dengan peningkatan kemampuan pemahaman matematis siswa dilihat dari nilai signifikansi disajikan dalam tabel berikut.

Tabel 8. Korelasi Sikap Siswa Terhadap Peningkatan Pemahaman Matematis

\begin{tabular}{ccc}
\hline Koefisien Korelasi & Nilai signifikansi & Keterangan \\
\hline 0,502 & 0,001 & $\mathrm{H}_{1}$ diterima
\end{tabular}

$\mathrm{H}_{1}$ : Terdapat korelasi yang positif antara sikap siswa terhadap pembelajaran matematika dengan menggunakan pendekatan open ended dan peningkatan kemampuan pemahaman matematis siswa.

Berdasarkan hasil perhitungan pada tabel 8, dapat dilihat bahwa nilai signifikansinya kurang dari 0,05. Karena nilai signifikansi kurang dari 0,05 maka $\mathrm{H}_{1}$ diterima. Dari hasil uji korelasi bivariate tersebut bisa disimpulkan bahwa terdapat korelasi yang positif antara sikap siswa terhadap pembelajaran matematika dengan menggunakan pendekatan open ended dan peningkatan kemampuan pemahaman matematis siswa. Adapun besarnya pengaruh sikap siswa terhadap peningkatan kemampuan pemahaman matematis dilihat dari kuadrat koefisen korelasi yaitu sebesar $0,502^{2} \times 100 \%=25,20 \%$. Jadi sebesar 25,20\% sikap siswa terhadap pembelajaran matematika dengan menggunakan pendekatan open ended berpengaruh terhadap peningkatan kemampuan pemahaman matematis.

\section{KESIMPULAN}

Berdasarkan hasil penelitan dan pembahasan yang telah dikemukakan sebelumnya, secara umum diperoleh beberapa kesimpulan hasil penelitian sebagai berikut. 
1. Terdapat pencapaian kemampuan pemahaman matematis siswa yang lebih baik dari siswa yang belajar dengan menggunakan pendekatan open ended daripada pencapaian kemampuan pemahaman matematis siswa yang belajar dengan menggunakan pendekatan konvensional.

2. Terdapat peningkatan kemampuan pemahaman matematis siswa yang lebih baik dari siswa yang belajar dengan menggunakan pendekatan open ended daripada siswa yang belajar dengan menggunakan pendekatan konvensional.

3. Hampir seluruhnya siswa memiliki sikap positif terhadap pembelajaran matematika dengan menggunakan pendekatan open ended.

4. Terdapat korelasi positif antara sikap sikap siswa terhadap pembelajaran matematika menggunakan pendekatan open ended dengan peningkatan kemampuan pemahaman matematis siswa.

\section{REFERENSI}

Budiman, H. (2019). Mengukur kemampuan berpikir reflektif matematis mahasswa pada materi diferensiasi dan integrasi numerik. PRISMA, 8(1), 58-67. https://doi.org/10.35194/jp.v8i1.380

Dewi, P. S. (2018). Efektivitas pendekatan open ended ditinjau dari kemampuan pemecahan masalah matematis. PRISMA, 7(1), 11-19. https://doi.org/https://doi.org/10.35194/jp.v7i1.340

Dini, M., Nuraeni, N., \& Anita, I. W. (2018). Meningkatkan kemampuan pemahaman matematis siswa SMK menggunakan pendekatan kontekstual pada materi SPLTV. IndoMath: Indonesia Mathematics $\quad$ Education, $\quad$ 1(1), 49. https://doi.org/10.30738/indomath.v1i1.2218

Ekici, D. I. (2017). The use of Edmodo in creating an online learning community of practice for learning to teach science. Malaysian Online Journal of Educational Sciences, 5(2), 91-106.

Fatwa, V. C., Septian, A., \& Inayah, S. (2019). Kemampuan literasi matematis siswa melalui model pembelajaran problem based instruction. Mosharafa: Jurnal Pendidikan Matematika, 8(3), 389-398.

Komala Sari, F., Syazali, M., \& Farida. (2016). Pengembangan media pembelajaran (modul) berbantuan Geogebra pokok bahasan turunan. Jurnal Pendidikan Matematika, 7(2), 135-151.

Krawec, J. L. (2014). Problem representation and mathematical problem solving of students of varying math ability. Journal of Learning Disabilities, 47(2), 103-115. https://doi.org/10.1177/0022219412436976

Maskur, R., Sumarno, Rahmawati, Y., Pradana, K., Syazali, M., Septian, A., \& Palupi, E. K. (2020). The effectiveness of problem based learning and aptitude treatment interaction in improving mathematical creative thinking skills on curriculum 2013. European Journal of Educational Research, 9(1), 375-383. https://doi.org/10.12973/eu-jer.9.1.375

Monariska, E. (2017). Penerapan metode mind mapping untuk meningkatkan kemampuan pemahaman konsep matematis mahasiswa pada mata kuliah kalkulus I. PRISMA, 
6(1), 17-31. https://doi.org/10.35194/jp.v6i1.25

Muhammad, G. M. (2017). Analisis kemampuan penalaran matematis mahasiswa pada mata kuliah struktur aljabar II (teori gelanggang). PRISMA, 6(1). https://doi.org/10.35194/jp.v6i1.29

Rahmi, M., Usman, \& Subianto, M. (2020). First-grade junior high school students' mathematical connection ability. Journal of Physics: Conference Series, 1460(1). https://doi.org/10.1088/1742-6596/1460/1/012003

Rizkiani, A., \& Septian, A. (2019). Kemampuan metakognitif siswa SMP dalam pembelajaran matematika dengan menggunakan pendekatan realistic mathematics education ( rme ). UNION: Jurnal Pendidikan Matematika, 7(2), 275-284.

Rohaendi, S., \& Laelasari, N. I. (2020). Penerapan teori piaget dan vygotsky ruang lingkup bilangan dan aljabar pada siswa Mts Plus Karangwangi. Prisma, 9(1), 65. https://doi.org/10.35194/jp.v9i1.886

Sari, J., \& Hayati, F. (2019). Analisis kemampuan pemahaman konsep matematis siswa smp pada materi kubus dan balok. Pi: Mathematics Education Journal, 2(1), 14-25. https://doi.org/10.21067/pmej.v2i1.2838

Septian, A., Darhim, \& Prabawanto, S. (2020). Geogebra in integral areas to improve mathematical representation ability Geogebra in integral areas to improve mathematical representation ability. Journal of Physics: Conference Series, 1613(1), 012035. https://doi.org/10.1088/1742-6596/1613/1/012035

Sudiarta, I. G. P., Sukajaya, I. N., \& Suharta, I. G. P. (2018). Investigation on students' mathematical online discussion: A case study in grade 8 SMPN 1 Denpasar. Journal of Physics: Conference Series, 1040(1). https://doi.org/10.1088/17426596/1040/1/012031

Suwarman, R. F. (2018). Analisis tingkat kemampuan pemahaman konsep mahasiswa pada mata kuliah pemrograman komputer. PRISMA, VII(2), 227-237.

Tsany, U. N., Septian, A., \& Komala, E. (2020). The ability of understanding mathematical concept and self-regulated learning using macromedia flash professional 8. Journal of Physics: Conference Series, 1657(1), 012074. https://doi.org/10.1088/17426596/1657/1/012074

Widiyawati, W., Septian, A., \& Inayah, S. (2020). Analisis kemampuan koneksi matematis siswa SMK pada materi trigonometri. Jurnal Analisa, 6(1), 28-39. https://doi.org/10.15575/ja.v6i1.8566

Widodo, S., \& Kartikasari, K. (2017). Pembelajaran pemecahan masalah matematis siswa sekolah dasar dengan model creative problem solving (CPS). PRISMA, 6(1), 57-65. https://doi.org/10.35194/jp.v6i1.28

Zengin, Y. (2019). Development of mathematical connection skills in a dynamic learning environment. Education and Information Technologies, 24(3), 2175-2194. https://doi.org/10.1007/s10639-019-09870-x 